Didier Faucher

École d'architecture de $\mathrm{N}$ antes faucher@nantes.archi.fr

Marie-Laure Nivet École d'architecture de $\mathrm{N}$ antes nivet@cerma.archi.fr

acadia'98

Association for C omputer-Aided Design in Architecture 


\section{Playing with Design Intents: Integrating Physical and Urban Constraints in CAD}

0 ur work deals with the exploration of a universe of forms that satisfy some design intents. That is, we substitute a "generate and test" approach for a declarative approach in which an object is created from its properties. In this paper we present an original method that takes into account design intents relative to sunlight, visibility and urban regulation. First of all we study how current $C A D$ tools have considered these properties until now. 0 urconclusion is that the classical design / simulation / analysis process does not suit design practices, especially in the early stages. W e think that an improved CAD system should offer the architectthe option of manipulating abstract information such as design intents.

W e define an intent as a conceptual expression of constraints having an influence on the project. For instance, a visual intent will be stated with no reference to vision geometry: "from this place, I want to see the front of the new building". W e show how to represent each of these constraints with a 3D volume associated to some characteristics. If some solutions exist, we are sure that they are included in these volumes. Forphysical phenomena we compute the volume geometry using the principles of inverse simulation. In the case of urban regulation we apply deduction rules.

Design intents are solved by means of geometrical entities thatrepresentopenings or obstructions in the project Computing constraint volumes is a way of guiding the architect in his exploration of solutions. Constraint volumes are new spaces that can restore the link between form and phenomenon in a CAD tool. 0 ur approach offers the designer the possibility of manipulating design intents.
Le jeu des intentions:

intégration de contraintes physiques et urbaines en CAO

$N$ otre objectif estd'offrir à l'architecte les moyens d'explorer un espace de formes défini à partir d'intentions de conception. Parallèlementà l'ap proche du type générer/ tester, nous proposons une approche déclarative dans laquelle l'objet est créé à partir de ces propriétés. N ous présentons dans cetarticle une méthode originale de prise en compte, dans un système de CAO, des intentions de conception relatives à l'ensoleillement, la visibilité et la réglementation urbaine. Dans un premier temps nous rela tons de quelle manière ces propriétés sont prises en compte dans le processus de conception assistée par ord ina teur. Les outils a ctuels imposent de construire une maquette numérique du projet avant de pouvoir en étudier les différentes caractéristiques. Le constat que nous pouvons dresser à la suite de cette étude est que le cycle modélisation d'une scène, simulation, analyse des résultats est mal adapté aux phases amont de la conception, lorsque le projetestencore mal défini. II paraitsouha itable, dans un système de CAO, d'autoriser l'architecte à manipuler des informations d'un haut niveau d'abstraction : les intentions.

$N$ ous définissons une intention comme l'expression, sous sa forme conceptuelle, d'une contrainte imposée ou non, influençant le projet Par exemple, une intention visuelle sera exprimée sans a voir recours à la géométrie de la vision qui lui est sousjacente : "de cette place je veux voir la façade du bâtiment projeté ". $N$ ous montrons pour chacune des contraintes considérées qu'il est possible de représenter ses conditions de satisfaction sous la forme d'un volume en trois dimensions doté de certaines caractéristiques. Ces volumes géométriques représentent des sous ensembles de l'espace portant les solutions, si elles existent La géométrie d'un volume estobtenue en utilisant les principes de la simulation inverse en ce qui conceme les phénomènes physiques, et par l'application de règles de déduction pour les contraintes réglementaires. Le calcul de ces volumes nous permet de guider l'architecte dans son exploration des solutions, masques ou évidements, qui résolvent les intentions énoncées quelque soitleur type.

Ces nouveaux espaces de recherche que constituent les volumes de contraintes rétablissent, dans une certaine mesure, le lien entre forme et phénomène en situation d'utilisation de l'outil informatique. Notre approche offre au concepteur la possibilité de mener un véritable jeu d'intention, en lui permettant d'étudier différentes hypothèses de conception. 
introduction

0 ur work deals with the exploration of a universe of forms that satisfy some design intents. That is, we substitute a "generate and test" approach for a declarative approach in which an object is created from its properties. This paper presents a hypothetical project dealing with the representation and the integration of physical and urban constraints in a design process. It is not concerned with the presentation of an operational system that can be integrated into a real design process.

During the early stages of a rchitectura I design, the designer must deal with various constraints. Some of these, (like urban regulation), take on an imperative character. Some others result only from design intents that follow the customer's requests or architect's desires. The visual impact of the project, its lighting qualities or its thermal and acoustical properties have to be considered. The choices made at this preliminary step will determine the global evaluation of the proposal. A nalysis tools, which are required to grasp such qualitative factors, are notyet integra ted into CAD systems. These latter only construct a geometric model that is used to simulate some phenomena or make realistic images. In fact these processes are only applied to validate or to invalidate some previous choices. These to ols require a full description of the structure and so they cannot be used before the last stage of design. The project has to be well-defined and well-known to be tested. The designer follows a generate and test process: he thinks about his project, makes some simulations on it and he observes the results. If his intents are not reached, the designer has to repeat the whole process. This is not always possible because of fixed decisions.

Moreover, as shown by some observations, the way an architect works is modified by the use of a CAD system. In such a context he is often w rapped up in geometrical aspects instead of considering physical and realistic features which determine the ambience of his project. Thus, sketching with CAD tools does not permit to state the design problem and to explore more than one solution. Such systems are only drawing and visualization tools. For some years, we have seen various attempts to remedy this situation. Especially, it has been demonstrated that reverse simulation methods lead to parameter values meeting lighting properties and visual constraints. By these means, the a rchitect devotes his time to examining multiple hypothesis of design instead of searching how to satisfy one given property. To play with design intents it is necessary to solve some difficulties: on the one hand, how to take into account the multiplicity of solutions; on the other hand how to integrate several phenomena.

In this paper three kinds of properties will be considered: urban planning regulations, lighting properties, and visual constraints. W e make a brief study of relative works in design context. W e will show how to represent these properties by a $3 D$ volume associated with some characteristics. $M$ echanisms to explore the set of solutions included in a constraint volume will be described. The solution space generated by the intersection of two or more constraint volumes will be outined. All these points will be studied in view of the architectural design. The pedagogic advantage of our approach will be discussed. Finally we will conclude with a discussion about the benefit of such a representation in the design process.

physical and urban constraints in design

The architect has usually to adhere to a program that takes into account some features of the site, the budgetallocated to the operation, as well as the wishes of the customer. The designer completes this document with his own considerations (aesthetic, functional...). The a rchitect playing with this set of para meters must come up with a suitable compromise in the form of an architectural or urban shape. Some elements, such as the visibility or the urban regulation of the site, are part of the program, or sometimes predominant (M VRDV 1996 ). The building position with regard to public roads, or the will to provide a good quality of sunlight to the project will have some direct effects on the constructed shape. M any computer to ols allow one to analyze projects from the point of view of different phenomena. W e present a brief sta te of the art in the following paragraphs.

W e consider exclusively numerical systems related to the three following aspects: sunlight, visibility and urban regulation. Though they bring a lot of elements to the reflection, we omitted the 
introduction

$N$ otre objectif est d'offrir à l'architecte les moyens d'explorer un espace de formes défini à partir d'intentions de conception. Parallèlement à l'approche du type générer/ tester, nous proposons une approche déclarative dans la quelle l'objet est créé à partir de ces propriétés. $C$ etarticle présente un travail prospectif sur la représentation et l'intégration de contraintes physiques et urbaines en conception. II ne s'agit en aucun cas de la présentation d'un système complètement abouti pouvant être intégré dans un processus de conception réel.

Durant la phase préliminaire d'un projet architectural, le concepteur est confronté à un ensemble de contraintes diverses. C elles-ci revêtent parfois un caractère incontournable (la rég lementa tion du site). D'a utres résultent de simples souhaits issus de la demande du client ou de la volonté de l'architecte/ urbaniste. C'est pendant cette phase d'ébauche que sont envisagées, entre autres, l'intégration visuelle de l'ensemble, sa qualité d'ensoleillement, ou encore ses performances thermiques et acoustiques. Les options retenues lors de cette étape détermineront la valeur globale de l'opération.

Les outils de CAO n'intèg rent pas les fonctions d'analyse nécessaires à l'appréhension des phénomènes évoqués. Par leur intermédiaire, l'architecte ne fait que modéliser la géométrie $d u$ projet, données nécessaires à la réalisation d'analyses et de rendus réalistes qui ne peuvent intervenir que pour valider ou invalider des choix déjà entérinés.

En effet, les outils classiques de simulation nécessitentune série de paramètres précis. Le projet doit être défini entièrement avant de pouvoir être testé. Le concepteur entre alors dans un processus d'essais/ erreurs : il pense son projet, le soumet à l'analyse et observe les résultats. Si ceux-ci ne correspondent pas à ses attentes, le processus conception/ simulation/ analyse doitêtre réitéré. C eci n'est pas to ujours possible étant donné le caractère irréversible de certaines décisions.

L'observation d'architectes en situation d'utilisation d'un système de CAO a montré un bouleversement des méthodes de conception. En effet, les facultés cognitives des architectes sont grandement absorbées par des détails géo métriques a u détriment des aspects physiques et réalistes déterminant en partie les ambiances du projet. Ainsi, le dessin, dans sa transposition sur l'écran d'un ordinateur, a perdu son rôle de mise en espace du problème, permettant à la fois le maniement des «certains» et des «probables». Il se trouve réduit à un moyen de visualisation et de présentation du projet Alors qu'un système informatique pourra it être un outil formidable d'exploration d'un univers des possibles, il ne fait que cloisonner l'architecte dans des procédures d'utilisation rigides. Depuis quelques années déjà, de nombreux travaux s'attachent à offrir de nouvelles alternatives.

En particulier, il a été montré que l'utilisation de la simulation inverse permetta it d'obtenir les conditions nécessaires à la réalisation de propriétés d'ensoleillement et de contraintes visuelles. Ayant par ce moyen permis au concepteur de réduire le temps passé à satisfaire une propriété donnée, nous souhaitons désorma is lui offrir la possibilité de mener un véritable jeu d'intention, en lui permettant d'étudier différentes hypothèses de conception. C et objectif soulève de nouvelles difficultés. C elles-ci sont liées, d'une partà la multiplicité des solutions envisa geables, d'autre part à la mixité des phénomènes qui entrent en jeu dans un processus de conception.

Dans cet article nous considérons tro is types de propriétés caractéristiques d'un projet urba in : les contraintes réglementaires, les propriétés d'ensoleillement, et les prop riétés d'accessibilité visuelle. $\mathrm{N}$ ous parcourons rapidement les trava ux relatifs au traitement de ces propriétés dans le cadre de la conception. N ous montrons pour chacune d'elles qu'il est possible de représenter ses conditions de satisfaction sous la forme d'un volume 3D doté de certaines caractéristiques. $\mathrm{N}$ ous présentons des mécanismes à mettre en $œ u v r e$ pour explorer l'ensemble des solutions inclus dans un volume de contrainte. N ous exposons également les difficultés inhérentes à la prise de connaissance d'un espace né de l'intersection de plusieurs volumes de contra intes. 
other methods voluntarily (graphical, a nalog...). The reader will find more details in (Siret 1997) concerning sunlight, (N ivet 1997) for visibility and (Dubois-M aury 1996) for urban regulation.

Sunlight $\mathrm{N}$ umerical methods dealing with sunlight can be classified in two categories: the "classical" systems of simulation which determine the distribution of sunny and shaded spaces during a temporal interval, in a given scene; and the know edge-based systems which give some help in the use of materials and the global organization of building forms. The former benefited from works in geometric modeling and in image synthesis. They use either perspectives or orthogonal projections ( $G$ rau, Johnsen 1995; G roleau, M a renne, $G$ adilhe 1995; Yezioro, Shaviv 1994 ), or ray tracing (Siret 1996 ). Sunlight maps (in two or three dimensions) are computed. It is possible to superimpose them on the numerical model of the site. Then the designer can judge the sunlight distribution and the potential interactions between the building and its neighbourhood. Knowledge-based systems can offer assistance to the energy saving (Silvestrini, Cacopardi 1993). From simple rules derived from statistics these systems propose solutions with a im to improve the project by modifying its materials.

Visibility. The increasing interest in a project's integration into a site, the legibility and the spatial composition encouraged the development of simulation tools about visibility and more particularly about the visual accessibility. A lot of numerical tools rest on the use of the isovist (Benedikt 1979) which can be defined as the set of points that are visible from a particular point or space. Several mathematical and/ or intuitive relations (Davis, Benedikt 1979) allow one to describe the architectural space (Benedikt, Burnham 1985; Do, G ross 1997). The isovist is also the kernel of some other systems dedicated to the study of urban (Hillier 1996) and landscaped (M iller, Morrice, and al. $1994)$ spaces. In urban environment we can also mention (M orin 1995) making use of a sunlight simulation tool (G rolea u, M arenne, $G$ adilhe 1995) to allow visual accessibility analysis. Softwa re can also help in the choice of locations for disruptive elements like high-tension lines (G ro 1991; Koglin, Zew e 1995).
Urban Regulation. Reflections on our modern cities' loss of urbanity have motivated the setting up of analysis and simulation tools. The development of geographical information systems (G IS) is an illustration of this. These systems try to integ rate a lot of geographical, economical (Lahti 1997) or environmental (Danahy, Hoinkes 1995 ) mea surements. They sometimes integrate multiple components like geometric modelers and rendering tools (Liggett, Jepson 1994).

Early works related to urban planning which have taken into account regulations made use of techniques derived from expert systems. Though they have brought some results (Elmakhchouni, 1985; Rabie, 1991) these approaches suffer from a lack of interaction and can not be used in the process of urban planning as it is exercised nowadays. This shortcoming is caused by the way information is represented in such systems. Adopting a more interactive approach, the system proposed in (Dupagne, Leclercq, Pirotte, 1988) is a vailable to the architects and other participants in the shaping of the urban form.

To our knowledge, little work has been done in this field during recent years. It seems that the study of the regulation aspects has been forsaken for the one related to negotiation processes. Today, the management of urban environment, especially in France, is also done by means of rules. These latter control the morphology of the building form. However, without reducing the urban planning to the application of urban regulation, it is necessary to notice its importance on the shape of a city. An interesting approach of the modeling of the link between building shape and urban shape is developed in (Dupagne, Teller 1997).

\section{design by intent}

The direct simulation tools which have been presented above only permit a validation of a project. They do not support the uncertainty inherent in a rchitectural design, especia lly in ea rly stages of the project. The architect then manipulates only some ideas or abstract shapes. For instance he can realize some annotated sketches which inform on the atmosphere and the genius loci of the project. The designer plays with these elements and thus simulates graphically (Lebahar 1983) different so-

acadia'98

Association for C omputer-Aided Design in Architecture 
Considérant les particularités du travail de conception en situation de projet, nous discutons de l'intérêt pédagogique de la représentation des contraintes de conception comme des éléments tangibles, parties intégrantes d'un système de CAO . $\mathrm{N}$ ous concluons sur l'apport d'un tel modèle du point de vue du contrôle et de la compréhension d'un objet en conception.

les contraintes physiques et urbaines en conception

Concevoir un projet revient pour l'architecte à répondre à un programme. Ce programme mentionne des caractéristiques du site, le budget alloué à l'opération, a insi que les volontés du client Le concepteur complète ce dossier par ses propres considérations (esthétiques, fonctionnelles, ...). L'architecte jouant avec l'ensemble de ces paramètres doit aboutir à la réalisation d'un juste compromis sous la forme d'une configuration architectura le ou urbaine.

Des éléments tels que la visibilité ou la réglementation $d u$ site font partie intégrante $d u$ programme, voire sont prédominantes (M VRDV 1996). Une simple contrainte d'alignement, ou encore la volonté d'assurer un ensoleillement de qualité au projet auront des conséquences directes sur la forme construite.

De nombreux outils informatiques, permettent d'analyser les projets sous l'angle de différents phénomènes. $\mathrm{N}$ ous en présentons un bref état de l'art dans les paragraphes suivants.

$\mathrm{N}$ ous parlons exclusivement des systèmes numériques relatifs aux trois aspects considérés dans cet article: l'ensoleillement, la visibilité et la réglementation urbaine. Bien qu'elles apportent beaucoup d'éléments à la réflexion, nous avons volontairement omis les autres méthodes (graphiques, a na logiques, ... ). N ous renvoyons le lecteur vers (Siret 1997) en ce qui concerne l'ensoleillement, (N ivet 1997) pour la visibilité et (Dubois-M aury 1996) pour la réglementation urbaine.

Ensoleillement. Les méthodes numériques peuvent être classées en deux catégories: les systèmes « classiques » de simulation qui pour une configuration donnée vont déterminer la distribu- tion des espaces ensoleillés et à l'ombre pour une plage temporelle donnée; et les systèmes à base de connaissances qui assurent assistance dans l'utilisation des matériaux et l'organisation globale des configurations. Les premiers ont bénéficié $d u$ développement des travaux en modélisation géométrique et en synthèse d'image. Ils utilisent so it des p rojections axono métriques et perspectives (G rau, Johnsen 1995 ; G roleau, M arenne, Gadilhe 1995 ; Yezioro, Shaviv 1994), soit les techniques de lancer de rayon (Siret 1996). Ils calculent pour une scène donnée les zones géométriques ensoleillées ou non dans une plage temporelle définie. L'observation directe de ces cartes d'ensoleillement (en trois ou deux dimensions) superposées à la maquette du site permet au concepteur de juger la répartition de l'ensoleillement et les interactions potentielles entre les constructions et leur environnement. D'autre part les systèmes à base de connaissances offrent une assistance à la maîtrise énergétique du projet (Silvestrini, Cacopardi 1993). A partir de règles simples issues de l'étude statistique des performances de configurations existantes ces systèmes proposent des solutions en vue d'améliorer le projet. C ellesci ne concernent généralement pas la géométrie du projet mais ses matériaux.

Visibilité. L'intérêt croissant des a ménageurs pour l'intég ration au site, la lisibilité et la composition spatiale ont encouragé le développement des outils de simulation de la visibilité et plus particulièrement de l'accessibilité visuelle. Une grande partie des outils numériques existants s'appuient sur l'utilisation de l'isovist (Benedikt 1979). L'isovist peut être défini comme l'ensemble des points qui sont visibles depuis un point ou un espace particulier. Plusieurs relations mathématiques et/ ou intuitives permettent dans une certa ine mesure de qualifier l'espace architectural (Benedikt, Burnham 1985 ; Do, G ross 1997). L'isovist est également le noyau d'autres systèmes dédiés à l'étude des espaces urbains (Hillier 1996) et des sites paysagers (M iller, M orrice, et al. 1994). En milieu urba in on peutégalement citer (M orin 1995) qui en détournant un logiciel de simulation solaire (G roleau, M arenne, Gadilhe 1995) permet d'obtenir des cartes d'accessibilité visuelle et de co-visibilité bi ou tridimensionnelles. 

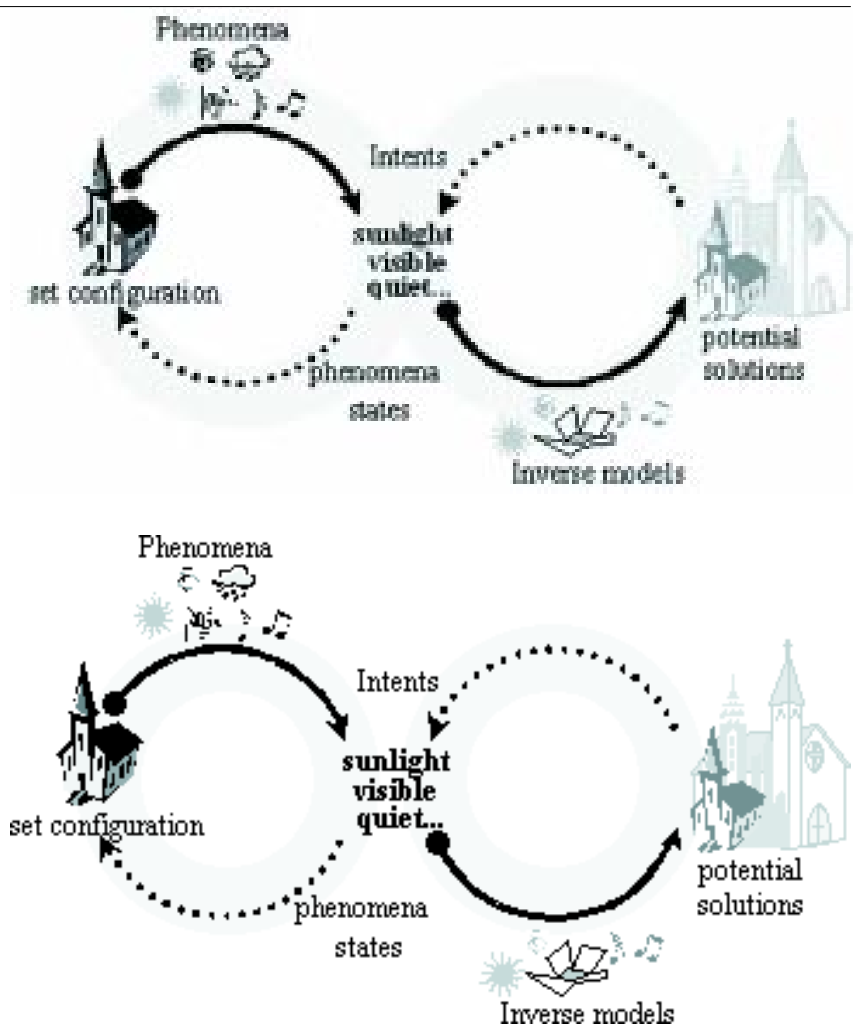

Figure 1. Interaction between simulation and design by intent [Interaction entre simulation et conception par l'intention.]

lutions. W ithout aiming to propose a computer version of a "sketch notebook" and thus fall into the Dr. Pangloss fallacy (Flemming 1994), it seems to be interesting, in a CAD system, to allow the architect to manipula te so me information of a high level of abstraction: that is to say intents. W e define an intent as a conceptual expression of constraints having an influence on the project. For in stance, a visual intent will be stated with no reference to vision geometry: "from this place, I want to see the front of the new building".

The usual cycle of simulation to ols is reversed manipulating intents in a computer aided design process. $0 \mathrm{n}$ the left side of Figure 1 the classic cycle is represented: numerical modeling of the scene, simulation, result a nalysis. This cycle leaves no room for graphical simulation as we defined it previously. Design is achieved outside of the system which only manipulates the geometry of the project 0 ur approach of design by intents is rep- resented on the right side of Figure 1. The a rchitect interacts with the system by expressing his intents. The system has enough know led g e to interp ret them as a space of solutions that the architect is free to explore graphically. W e stress the fact that the system produces only geometrical shapes. W e intentionally leave the architectural interpretation (concept, ma terials, a esthetic or economical qua lities... ) to the designer in order to preserve the creative nature of this process.

In a simulation cycle (left part of Figure 1) a new numerical model of the scene starts the iteration. In the inverse approach (right part of Figure 1) a new cycle starts by the statement of new intents or by the refinement of the previous ones. The two approaches, direct simulation and design by intents, a re complementary. The results of one can be input data for the other. The introduction of intents within a CAD system induces a new formalism of representation. This is the object of the following section.

\section{modeling design intents}

In the following, we speak of "intents" when we refer to the interaction designer/ project/ CAD tool. W e use the term "constraint" when these intents are manipulated in the computer system.

W e conjecture that a class of intents can be modeled by some geometric volumes of constraint. These geometric volumes represent subspaces in which the solutions are included (if they exist). The geometry of a volume representing a set of solutions is obta ined using the principles of inverse simulation when treating physical phenomena, and using deduction rules for urban regulation. The inverse simulation derives its name from resea rch done in physics or in mechanics. By reversing the equations related to a phenomenon, it is possible to find the input parameters of an equation system satisfying a given state.

The visibility and sunlight phenomena can be expressed following the same principle based on the notion of rays (left side of Figure 2 ). Reversing sunlight or visual ray (Figure 2 on the right) allows to find the corresponding constraint satisfaction subspace: the volume of constraint. 

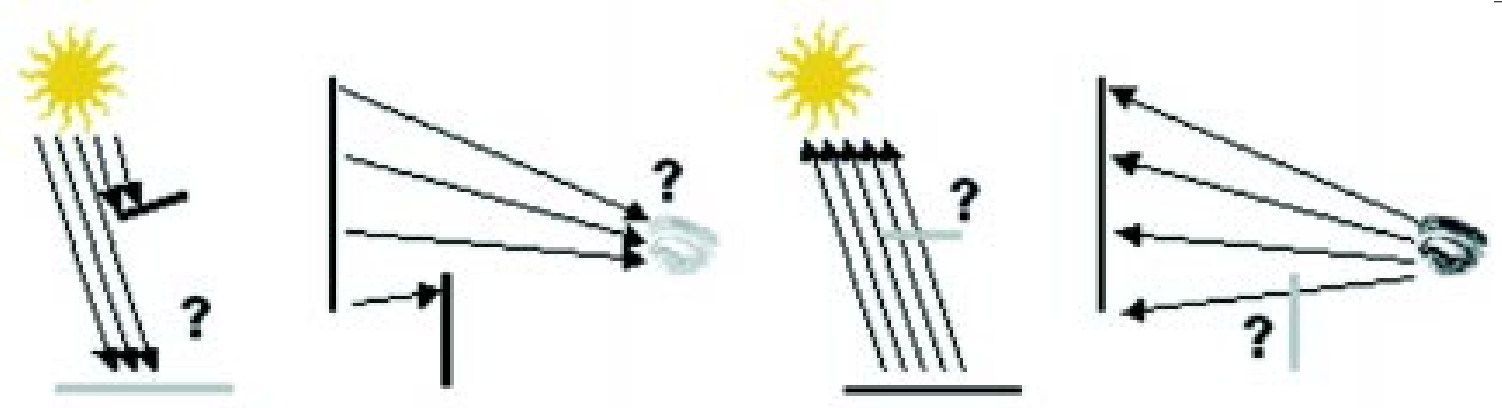

Figure 2. Direct and inverse line of sight or sunbeam. [Rayon direct et inverse, visuel et solaire.]

II existe également des outils d'assistance à l'implantation d'éléments perturbants comme les lignes hautes tension (G rob 1991; Koglin, Zewe 1995).

Réglementation. La réflexion engagée sur la perte d'urbanité de nos villes modernes a conduit à la mise en place d'outils d'analyse et de simulation évolués. Le développement des systèmes d'informations géographiques (SIG) en est une illustration. C eux-ci tentent d'intég rer de nombreuses dimensions, géographiques bien sûr, mais aussi économiques (Lahti 1997) ou environnementales (Danahy, Hoinkes 1995). La tendance actuelle est à l'intég ration de nombreux composants: modeleur géométrique, SIG, outil de rendu réaliste (Liggett, Jepson 1994).

Les premiers travaux relatifs à la planification urbaine, prenant en compte les réglementations, ont fa it usage des techniques issues des systèmes experts. Bien qu'ayant donné quelques résultats (Elmakhchouni, 1985; Rabie, 1991 ) cette approche, de partle peu d'interaction qu'elle offre, s'est avérée peu viable dans le processus d'a ménag ement urba in tel qu'il est pratiqué de nos jours. Cette lacune provient du mode de représentation de l'information dans de tels systèmes. Adoptant une logique plus participative, le système proposé dans (Dupagne, Leclercq, Pirotte, 1988 ) s'ouvre aux architectes et maîtres d'ouvrage.

A notre connaissance, peu de travaux ontété réalisés depuis. II semble que l'étude des aspects rég lementaires ait été déla issée au profit de celle des processus de négociations. $0 \mathrm{r}$, la maîtrise de l'environnement urbain, notamment en France, passe aussi par la règle. C elle-ci exerce un contrôle sur la morphologie des unités construites. Sans réduire la planification urbaine à la mise en application d'une réglementation, il faut toutefo is noter l'importance de cette dernière sur la forme d'une ville. Une approche intéressante de la modélisation de ce lien entre forme construite et forme urbaine est développée dans (Dupagne, Teller 1997).

\section{conception par l'intention}

Les outils de simulation directe qui viennent d'être présentés permettent une validation du projet. Cependant ils ne supportent pas le flou qui caractérise le travail de conception, notamment dans ses phases initiales. En effetl'architecte dans un premier temps ne manipule que des idées ou des formes abstraites. Cela peut se traduire dans le processus de conception par la réalisation de croquis annotés qui renseignent sur les a mbiances et l'esprit du projet. Le concepteur joue avec ces éléments et ainsi simule graphiquement (Lebahar 1983 ) différentes possibilités. Sans pour autant proposer une version informatisée du «carnet de croquis », et a insi tomber dans la Dr Pangloss fallacies (Flemming 1994), il pa raît souhaitable, dans un système de CAO, d'autoriser l'architecte à manipuler des informations d'un haut niveau d'abstraction : les intentions.

$\mathrm{N}$ ous définissons une intention comme l'expression, sous sa forme conceptuelle, d'une contrainte imposée ou non, influençant le projet. 


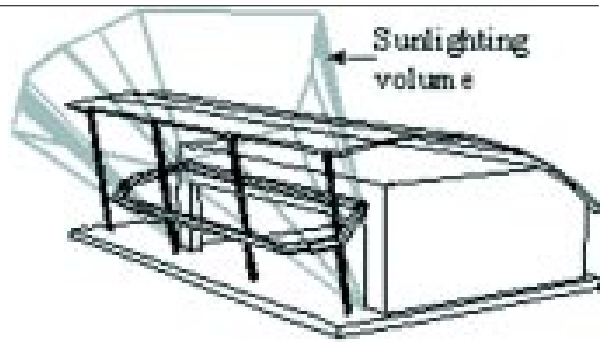

Figure 2a. Sunlight Intent "The front of the project must be sunlit in the middle of the evening in winter." Parameters needed: time period, the qualifying surface represented as a polygon. $Q$ ualification: sunless, sunlit

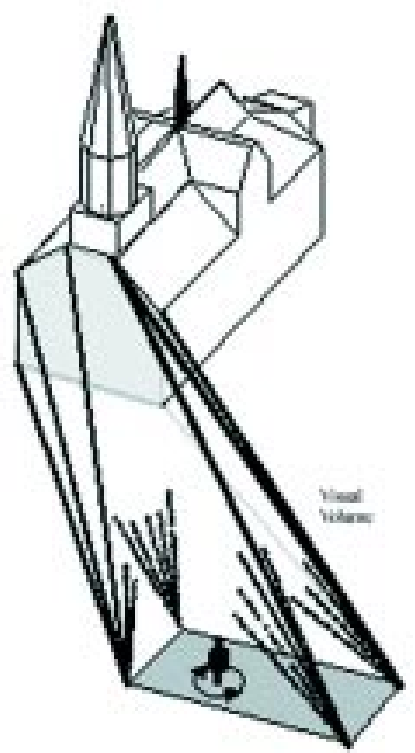

Figure $2 b$. Visibility Intent "From the square, the observer must be able to see the front of the church." Parameters needed: O bserver, defined by his view field and location; object in the environment $Q$ ualification: to see, not to see.

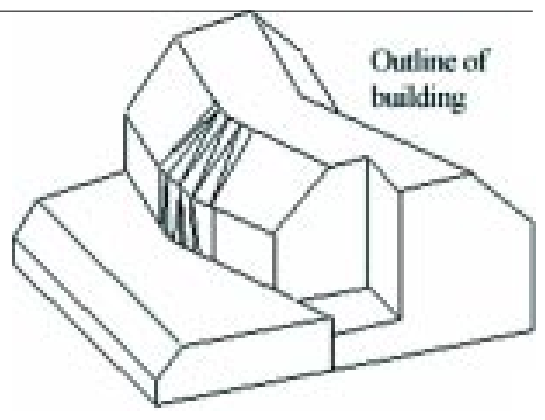

Figure 2c. Urban Intent "The builing must be included in the maximal volume of the site." Parameters needed: plot geometry; maximum building heights; width of the surface to be be built depth of neighboring houses. Q ualification: can be built cannot be built
Urban regulation is not based on a physical phenomenon but on the politics of management of the city's spaces. Here, we only consider rules influencing the building's shape. In France, these rules are generally defined in articles of a "plan d'occupation des sols" (POS). A POS is a complete document in which plans mention existing constructions and zones of regulation. Every regulation article participates in the definition of one or several volumes of constraints.

\section{geometric representation of constraints}

A survey of the representation for each kind of constraints is developed in (Siret 1997) for sunlight, (N ivet, Siret 1998) for the visibility and (Faucher 1998) for urban regulation. W e present the main para meters of each model in Figures $2 a$ c. Each figure indicates an example statement of intent, summarizes the essential parameters of the model, and shows an example of the constraint volume geometry.

W e can ensure that if a solution to the expressed intent exists, it is included in the volume of constraint computed by the system. A solution is a geometrical entity, which satisfies a constraint. W e insist on the fact that the architectural meaning of this raw shape is given by the designer and not by the CAD system. For example a surface or a volume will be interpreted as a building front, a sunshade or a tree. An empty space will be seen as a street, an aperture or a passage.

In an a rchitectural context, an intent is rea lised by manipulating some full elements or empty spaces. This is the reason why it is possible to treat the descriptions see/ don't see, sunlit/ sunless, can be built/ can not be built, in a same way. Thus constraints of different kinds a re considered homogeneously by introducing the notion of negative or positive constraint: constraints which are resolved using one or several solid elements are defined as positive; constraints which a re resolved using one or several empty spaces are defined as negative. As for sunlight and visual properties, the positive constraints are resolved adding some solid elements intercepting all the rays of constra int volumes. The negative constraints imply a total hollowing out of them. In the case of urban rules, the solutions do not depend on the direction of rays. The only thing 
Par exemple, une intention visuelle sera exprimée sans avoir recours à la géométrie de la vision qui lui est sous-jacente : "de cette place je veux voir la façade du bâtiment projeté ».

$M$ anipuler les intentions dans un processus de conception informatisé inverse le cycle habituel d'utilisation des outils de simulation comme le montre la Figure 1. À gauche est représenté le cycle classique : modélisation d'une scène, simulation, analyse des résultats. Celui-ci ne laisse aucune place à la simulation graphique dans le sens défini ci-dessus. La phase de conception, en tant que telle, est réalisée en dehors du système, lequel ne manipule que la géométrie du projet. La partie droite figure notre approche de conception par l'intention. L'architecte interag it avec le système en énonçant ses intentions. Le système possède la connaissance suffisante pour les interp réter sous la forme d'un espace de solutions géométriques que l'architecte est libre d'explorer graphiquement. Insistons sur le fait que le système ne produit que des formes géométriques. L'interprétation architecturale (parti, ma tériaux, qua lités esthétiques et économiques...) est volontairement la issée au concepteur afin de préserver la dimension créative.

Dans un cycle de simulation (partie gauche du schéma) l'itération est amorcée par la donnée d'une nouvelle configuration. Dans l'approche inverse (partie droite) cette amorce est assurée par l'énoncé de nouvelles contraintes ou par le raffinement des intentions précédentes. Les deux approches, modélisation classique et conception par l'intention sont complémentaires, les résultats de l'une pouvant servir de données à l'autre. L'introduction au sein d'un système de CAO, de la notion d'intention, telle que nous venons de la définir induit la mise au point d'un nouveau formalisme de représentation. Ceci fait l'objet de la section suivante.

modélisation des intentions de conception

Dans la suite, nous parlons d'intention lorsque nous faisons référence à l'interaction concepteur / projet/ outil de conception. $\mathrm{N}$ ous utilisons le terme contrainte lorsque ces intentions sont manipulées au niveau du système informatique. L'hypothèse que nous avançons et que nous défend ons est qu'il existe une classe d'intentions pouvant être

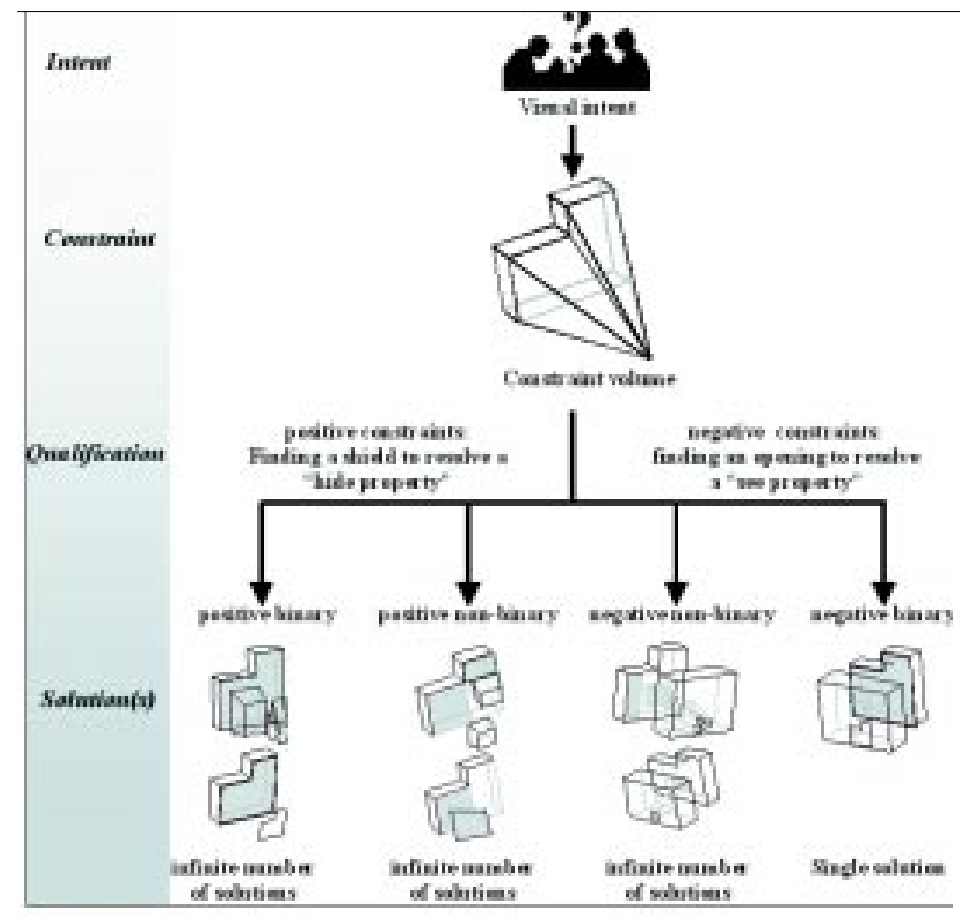

Figure 3. The ratio of description/ number of solutions. [Rapport qualification / nombre de solutions.]

modélisées par des volumes géométriques de contra inte. $C$ es volumes géométriques rep résentent des sous ensembles de l'espace portant les solutions, si elles existent. la géométrie d'un volume représentant l'espace des solutions est obtenue en utilisant les principes de la simulation inverse en ce qui concerne les phénomènes physiques, et par l'application de règles de déduction pour les contraintes rég lementa ires.

La simulation inverse tire son nom de recherches effectuées en physique ou en mécanique, où par l'inversion des équations relatives à un phénomène précis, il est possible de connaître les paramètres d'entrée d'un système d'équation répondant à un état donné.

Les phénomènes d'ensoleillement et de visibilité peuvent s'exprimer suivant le même principe. En effet ils sont tous les deux supportés par la notion de rayon (Figure 2 à gauche). L'inversion des rayons solaires ou visuels (Figure 2 à droite) permet de connaître la zone de l'espace engagée dans 


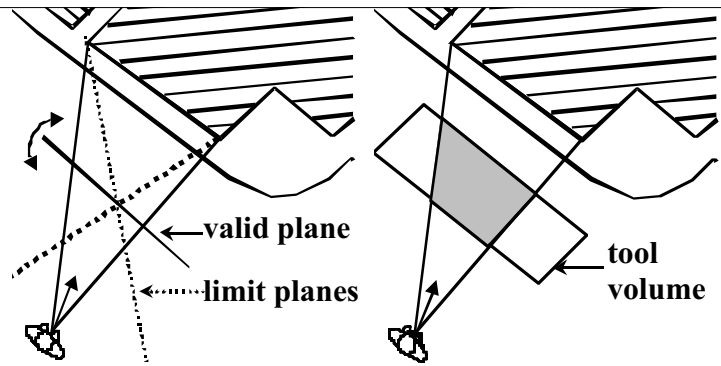

Figure 4. Principles of interaction with solutions. [Principes d'interaction avec les solutions.]

to be considered in the determination of the solutions is the presence or the absence of matter.

In the examples presented hitherto, we always considered binary intents, that is to say some "all or nothing" sta tements: "see entirely or don't see at all." In many cases, it is interesting to study intents finding their solutions between these two states. In another words we have to enrich the formalism to permit the statement of non-binary intents like "build at least $50 \%$ of the frontwall in the border of road" or "from this street see a part of the front of the new building." Applying the representation we chose, the state of an intent (positive, negative, binary, non-binary) generates a constraint. The subspace including the potential solutions is represented by a volume. The geometry of a constraint volume does not depend on the description it is linked to. This description is taken into account during the exploration step of the solutions space (Figure 3 ). A negative binary constraint is a chieved only if the corresponding volume is empty. If the constraint is already satisfied, the system prevents any addition of solid in the volume. $0 \mathrm{n}$ the contrary, if the constraint is not satisfied, the resolution consists in hollowing out the constraint volume. This solution is unique; it is necessary and sufficient. The resolution of a positive binary constraint is more problematic, insofar as an infinity of solutions exist. Indeed, in the case of a visual constraint, an infinity of obstructions that cut all the lines of sight can be defined. Finding a solution is the same as choosing a obstructing object among this infinity. The process is identical in the case of the non-binary solutions (positive or negative). For example in the case of the "boundary line rule, used in the POS, only the solid/ empty ratio is imposed: the designer has to find a distribution of the wall along the road

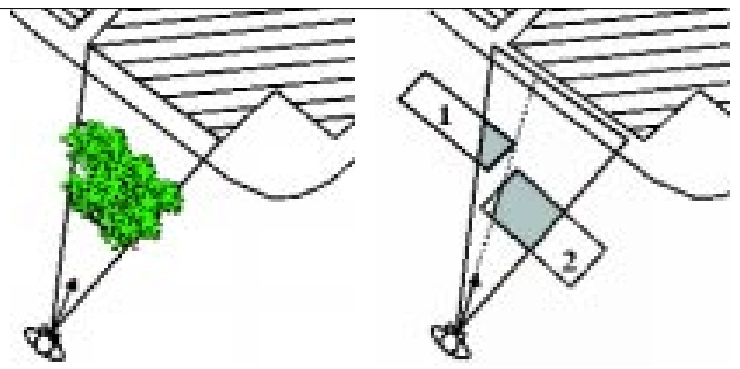

that satisfies this condition.

explorating solutions of a constraint

$W$ e stress again the fact that our research objectives are not to propose an automaticallygenerated solution. W e wish to offer the designer tools that he will be free to use during the design process. For these reasons, we can not limit ourselves to enumerating all the solutions or randomly choose one solution. Such a procedure would be inapplicable considering the big number of shapes to examine. Keeping this philosophy in mind, we study first the possibilities for solutions in the case of a single constraint.

Positive Binary Constraint For such a constraint, the simplest case consists in manipulating a structural plane holding a blocking object (Figure $4 a)$. Applying some geometric transformations on this plane (rotations and shifts) the user manipulates the blocking object ind irectly. The system controls the degrees of freedom of the plane and computes the minimal blocking object. This object is the intersection surface between the plane and the constraint volume. A nother possibility is to use a so called tool volume which intersects completely the constraint volume as it is shown on Figure $4 \mathrm{~b}$. A tool volume is represented in the horizontal plane. Its intersection with the constraint volume is indicated in grey. It constitutes a n exact blocking object $A$ designer could interpret this volume as a group of trees (Figure $4 \mathrm{c}$ ). N ote that such a volume can be reduced to a surface.

In order to allow more flexibility in the manipulation of the blocking objects, we also propose to explore the possibilities of non-connected solutions. Extending the previously described inter- 
la résolution de la contrainte: le volume de contrainte.

La réglementation urbaine ne s'appuie pas sur un phénomène physique. mais sur une politique d'organisation des espaces d'une ville, qu'ils soient publics ou privés. $\mathrm{N}$ ous ne considérons ici que les règles intervenant sur la morphologie du bâti. En France, ces règ les sont généra lement définies dans les articles d'un plan d'occupation des sols. Un plan d'occupation des sols est un dossier complet comprenant: des plans mentionnant les constructions existantes et les zones de réglementation, des plans d'épannelage, et des règ lements applicables dans chaque zone. Chaque article du règlement participe à la définition d'un ou plusieurs volumes de contrainte.

représentation géométrique des contraintes

L'étude des représentations propres à chaque type de contrainte est développée dans (Siret 1997 ) pour l'ensoleillement, (N ivet 1998 ) pour la visibilité, (Faucher 1998) pour la réglementation urbaine. $\mathrm{N}$ ous présentons ci-après un ta bleau reprenant sans les détailler, les principaux paramètres des trois modèles. C e tableau comporte trois colonnes. La première indique le type de contrainte considérée et donne un exemple d'énoncé réalisable. La seconde colonne énumère les paramètres essentiels du modèle. Enfin, la dernière colonne présente un exemple de la géométrie du volume.

$\mathrm{N}$ ous pouvons assurer que s'il existe une solution à l'intention énoncée par le concepteur, elle est incluse dans le volume de contrainte calculé par le système. Une solution est une configuration géométrique brute assurant la réalisation d'une contrainte. Insistons sur le fait que seul l'architecte lui donne une signification architecturale. Par exemple une surface ou un volume trouveront leurs équivalents dans une façade, un pare-soleil, ou un arbre. Un vide sera interprété comme une rue, une ouverture, un passage.

Dans le cadre de la conception a rchitecturale, assurer la réalisation d'une intention, revient à manipuler des éléments pleins ou vides. C eci nous offre la possibilité d'uniformiser le principe de résolution des contraintes en traitant d'une même façon les qualifications voir/ ne pas voir, au soleil/ à l'ombre, inconstructible/ constructible. De la sorte des contraintes de type différent peuvent être résolues de façon homogène en introduisant la notion de contrainte négative ou positive :

- les contraintes dont la réalisation passe par la mise en place d'un ou plusieurs éléments matériels sont des contraintes positives ;

- les contraintes réalisées par l'absence de matière sont des contraintes négatives.

S'agissant des propriétés d'ensoleillement et de visibilité les contraintes positives sont résolues par l'ajout d'éléments matériels interceptant l'ensemble des rayons du volume de contrainte. Les contraintes négatives impliquent un évidement to tal de ce dernier. Dans le cas des règles urba ines, les solutions incluses dans le volume de contrainte ne dépendentpas de la direction d'un rayon. Seule la présence ou l'absence de matière est prise en compte dans la détermination des solutions.

Dans les exemples présentés jusqu'ici, nous avons toujours considéré des intentions binaires, c'està-dire des énoncés qui s'expriment en « tout ou rien »: "voir entièrement ou ne pas voir du tout ». O $r$ dans bien des cas, il est intéressant d'étudier des intentions trouvant leurs solutions entre ces deux états. II s'agit donc d'enrichir le formalisme en permettantl'énoncé d'intentions non binaires: "construire au moins la moitié de la façade à l'alignement», ou encore "de cette rue voir une partie de la façade du nouveau bâtiment».

En appliquant le mode de représentation que nous a vons choisi, la donnée d'une intention (positive, négative, binaire, non binaire) eng endre une contrainte. L'espace portant les solutions potentielles est représenté par un volume. La géométrie du volume d'une contrainte ne dépend pas de la qualification qui lui estatta chée. En revanche, cette qualification entre en jeu lors de l'exploration de l'espace des solutions (Figure 3 ).

Une contrainte négative bina ire est réa lisée si et seulement si son volume associé est la issé libre. Si la contrainte est déjà satisfaite, le système empêche tout ajout de matière à l'intérieur du volume. Si au contraire la contrainte n'estpas satisfaite, la résolution se fait par l'évidement to tal du volume 

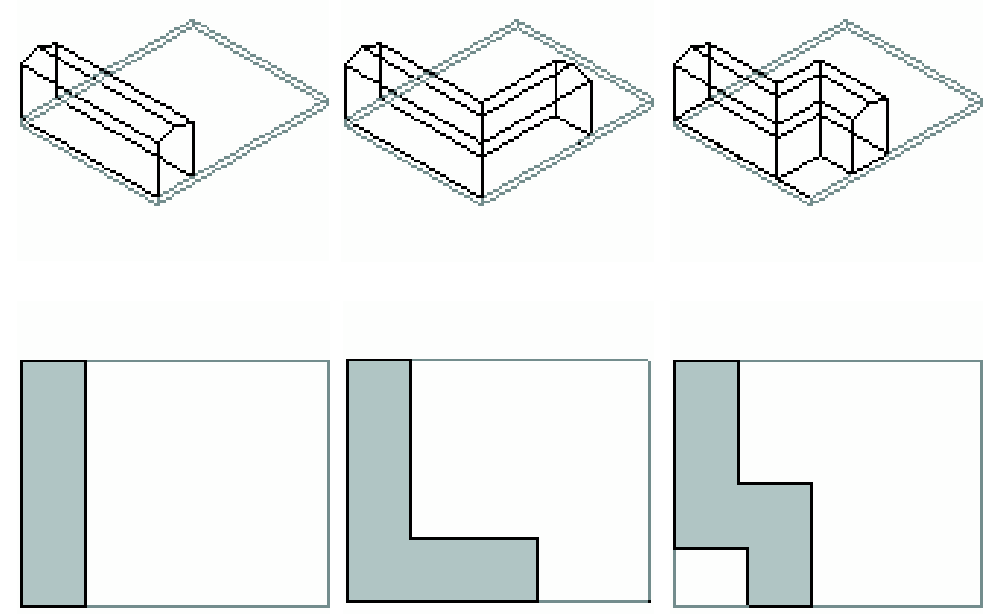

Figure 5. A non-binary constraint example: building land surface. [Un exemple de contrainte non binaire, l'emprise au sol.]

action means, we allow the designer to manipulate several tool volumes. The user indicates the number of elements to put in order to satisfy the constraint In Figure $4 d$, a first to ol volume is drawn (volume 1 ). It does not resolve to tally the constraint Consequently the system computes the complementary constraint volume. The user can then put a second tool volume (volume 2 ) in order to complete the first occluding element.

$N$ on-bina ry C onstraint. W e recall here that a non-binary intent is a statement that introduces a new degree of freedom in the satisfaction of a constraint Let us take the case of the maximum building surface. It requires that only $80 \%$ of the plot surface be constructed. This constraint can be satisfied in different ways as show $n$ in Figure 5.

The user distorts his solution while the system ensures that the surface respects the stated percentage. Such a constraintcan be also solved manipulating directly the building plot surface. In this case, the system reduces the solution space and proposes a new constraint volume according to the given percentage. So the new volume can be explored as a binary constraint one.
In a more general way, all non-binary constraints can be treated by graphic interaction on the solution or by refinement of the intent. The exploration by refinement process permits a real ga me with intents. In a real situation, the multiplicity of the constraints requires this game because it is often difficult to find a compromise without coming back to the initial intents.

\section{interaction in multiple constraints}

The statement of several intents brings some situations of competition or opposition between them. Searching for a solution requires in the first place knowing the usable zones (i.e. where it is possible to putsome solids). This is why the negative binary intents must be solved in priority by hollowing out all the volumes of the negative bina ry constraints. The search space is thus reduced to the volumes of the remaining constraints, minus their possible intersections with the volumes of negative binary constraints. The geometric representation of intents allows seeing the zones of the space where they interact. These subspaces a re the zones of intersection between the constraint volumes. These zones are qualified by all the intents engaged. Then we have to find a solution that can be inserted in this intersection space.

Figure 6 a shows the competition between a visual and a sunlight constraint The rays which define them, are not directed towards the same direction. A solution has to interceptall the rays in both directions. W e can work outside of the intersection of the constraint volumes, thus we go back to the exploration of several unique constraints; or inside the intersection space exploring all the constraint volumes simulta neously. The intersection betw een several constraint volumes ra rely ensures the complete resolution of all the considered intents. That is to say that one blocking object can not satisfy all the constra ints completely. How ever, it is of interest to work in this space when the solution has to be optimized. This sea rch is difficult because of the complex geometry of the intersection volume, combined with the fact that we have to take into account the direction of the rays. A first approximation of the solution consists in offering the whole intersection volume (Figure $6 \mathrm{~b}$ ). However some other obstructions a re acceptable (Figure $6 \mathrm{c}$ ). 
de contrainte. C et évidement est unique, il est nécessaire et suffisant.

La résolution d'une contrainte positive binaire est plus problématique dans la mesure où il existe une infinité de solutions. En effet, si nous prenons le cas d'une contrainte visuelle, une infinité de masques coupent to us les rayons visuels. Trouver une solution revient alors à choisir un masque parmi cette infinité. L'approche est identique dans le cas des solutions non bina ires (positives ou négatives). Par exemple dans le cas de la règle d'alignement, la répartition des façades sur la voie n'est pas imposée. Seul le rapportplein/ vide estconsidéré.

exploration des solutions d'une contrainte unique Insistons sur le fait que l'objectif de notre recherche n'est pas de proposer une solution entièrement automatique au concepteur. $\mathrm{N}$ ous souhaitons mettre à sa disposition des outils qu'il utilisera à son grès au cours du travail de conception. Pour ces raisons, nous ne pouvons nous contenter d'une énumération exhaustive des solutions ou d'un tirage aléatoire parmi celles-ci. De plus une telle procédure serait inapplicable étant donné le grand nombre de configurations à examiner. En gardant présentà l'esp rit cette philoso phie, nous étudions, dans un premier temps, les possibilités envisa geables pour guider l'explo ration des solutions dans le cas d'une contrainte unique.

Contrainte positive binaire. Pour une telle contrainte, le cas le plus simple consiste à manipuler un plan portant le masque (Figure 4 a). En appliquant des transformations géométriques sur ce plan (rotations et translations) I'utilisateur manipule indirectement le masque. Le système contrôle les degrés de liberté du plan et calcule le masque minimal, intersection exacte entre le plan et le volume de contrainte.

Une autre possibilité consiste à passer par l'intermédiaire de volumes outils qui intersectent complètement le volume de la contrainte. C'est ce que nous montrons sur la Figure $4 \mathrm{~b}$. Un volume outil est représenté dans le plan horizontal. Son intersection avec le volume de contrainte est indiquée en gris. Elle constitue un masque exact. Un urbaniste pourrait interpréter ce volume comme un groupe d'arbres (Figure $4 \mathrm{c}$ ). $\mathrm{N}$ otons que dans

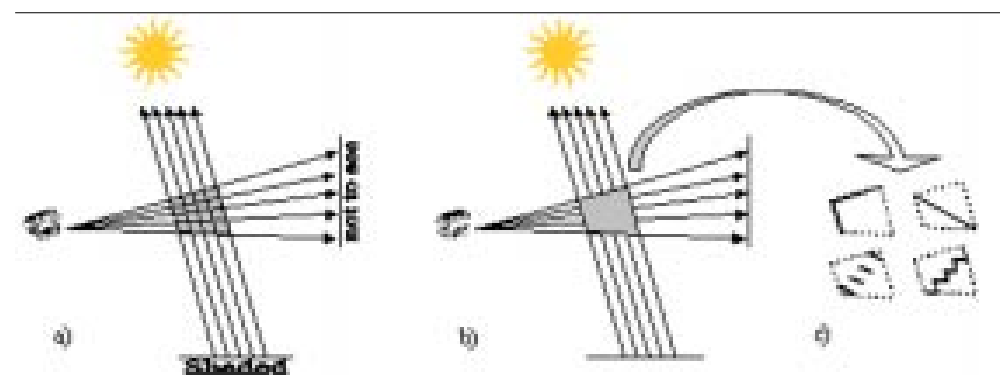

Figure 6 . Solutions in the intersection of two constraints. [Solutions à l'intersection de deux contraintes.]

sa plus simple expression un volume peut être réduit à une surface.

A fin d'être plus souple dans la manipulation des masques, nous proposons aussi d'explorer les possibilités de solutions non connexes. $N$ ous étendons pour cela le mode d'interaction défini précédemment en autorisant la manipulation de plusieurs volumes outils. L'utilisateur indique le nombre d'éléments à placer. Sur la Figure $4 d$, un premier volume outil a été choisi. Celui-ci ne répondant pas intégralement à la contrainte, le système calcule le volume de contrainte complémentaire. L'utilisa teur peut alors placer un second volume outil pour compléter le premier masque.

Contrainte non binaire. Rappelons qu'une intention non binaire est un énoncé introduisant un degré de liberté supplémentaire dans la résolution d'une contrainte. Prenons le cas de la règle d'emprise au sol. C elle-ci exige que seuls $80 \%$ de la surface au sol de la parcelle soient construits. Cette contrainte peut être réalisée de plusieurs façons comme le montre la Figure 5.

L'utilisateur déforme sa solution tandis que le système assure que cette surface respecte le pourcentage énoncé. Une telle contrainte peut être également résolue en manipulant directement la surface d'emprise au sol. Dans ce cas le système restreint l'espace des solutions en proposant un nouveau volume de contrainte respectant a priori les $80 \%$ d'emprise au sol. Ce dernier pouva nt subir des translations ou rotations. $C$ eci nous ramène à l'exploration d'une contrainte binaire, le nouveau 


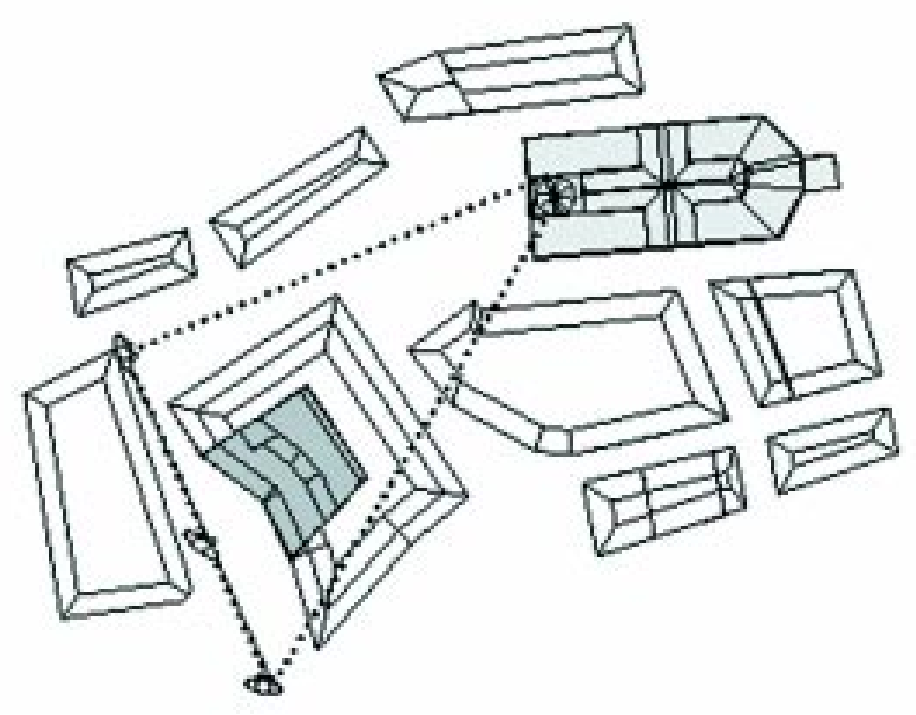

Figure 7. The site or plan geometry. [Le site.]
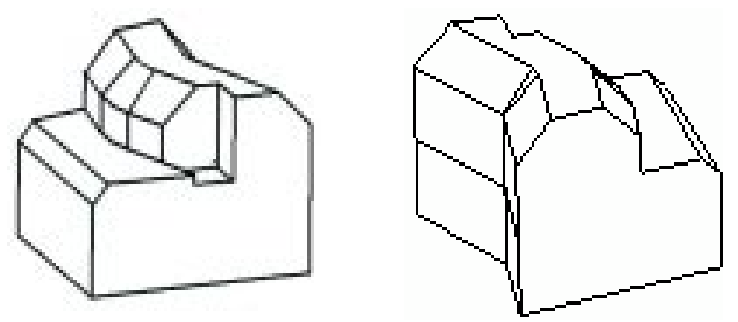

Figure 8. 0 utine of the building. [Le gabarit constructible.]

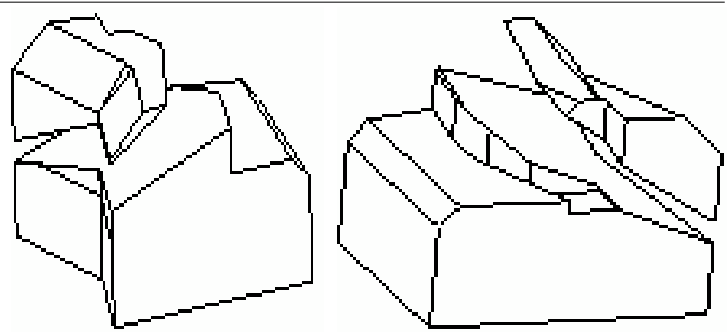

Figure 9: Hollowing out building outline. [Évidement du gabarit]
W e are currently proceeding to the survey of the properties associated with intersections of constraint volumes. W e classify the faces and the edges of such an intersection with the object in order to extract search methods for solutions. This classification will allow us to know the function of each volume face in the resolution of the constraints (rate of resolution, constraint involved). This study will help us to assist the designer in his search for an optimal solution.

\section{an example}

The example presented in this section shows how visual and urban intents are taken into account in our system. The project consists of building a cultural centre in a given urban environment. An auditorium, a reception hall, and various administrative office spaces are included in the program. Besides, the authorities of the city wish to keep a good visibility of a great building near the project land plot Furthermore the urban rules lay dow $n$ the respect of the building outline. Figure 7 presents in dark grey the land plot to be build and in light grey the monument which the visual constraint is based on (in stippled). The outline building rule gives a first approximation of the volume approved for development (Fig ure 8). In concrete form, the user inputs his visual intent in the system by drawing the position of the observer (point, segment line, or convex plane surface) and by pointing out the target (a surface). The user selects the land plot to be built and he choices the rules to apply. In this example the maximal volume rule, the height rule and the standing back rule are used. The building land surface is not considered.

The visual intent "see the monument" is a negative binary constraint competing with the positive non-bina ry constraint volume defined by the urban regulation (Figure 10 ). W ith regard to the priority rule, the system proposes to hollow out the outline volume 9 (Figure 9).

The resolution of the visual intent leads to a volume sketch for the architect to work with. He can, for example, plan to use the upper part for the auditorium. The reception hall will take up the low er part of the volume. The designer thinks about building a big picture window on the back but he wishes to conserve the privacy of the hass as well. 
volume pouvant être construit intég ralement

Plus généra lement toute contra inte non binaire peut être explo rée par interaction graphique sur la solution ou par raffinement de l'énoncé de la contrainte. Le processus d'exploration par raffinement permet un véritable jeu sur les intentions. En situation réelle, la multiplicité des contraintes rend ce jeu nécessa ire car il est so uvent difficile de trouver un compromis sans revenir sur les intentions initiales.

interaction entre contraintes multiples

L'énoncé de plusieurs intentions amène des situations de concurrences, voire d'oppositions entre celles-ci. Rechercher une solution nécessite en premier lieu de connaître les zones utilisables (i.e. où il est possible de mettre des éléments matériels). $C$ 'est pourquoi les intentions négatives binaires doivent être résolues en priorité par évidement de to us les volumes des contra intes nég a tives bina ires. L'espace de recherche des solutions est a insi réduit aux volumes des contra intes restantes, diminués de leurs éventuelles intersections a vec les vo lumes des contraintes négatives binaires.

La représentation géométrique des intentions permet de voir facilement les zones de l'espace où elles interagissent. II s'agit des zones d'intersection entre les volumes de contraintes. C es zones sont qualifiées par l'ensemble des intentions y intervenant. II s'agit alors de trouver une solution pouvant s'y insérer.

Soient une contra inte visuelle et une contra inte d'ensoleillement (Figure 6a). Les rayons qui les définissent ne sont pas dirigés dans la même direction. Une solution doit pourtant intercepter to us les rayons de l'une et l'autre. II est possible de travailler soit :

- en dehors de l'intersection des volumes de contrainte et ainsi se ramener à l'exploration de plusieurs contra intes uniques;

- dans l'intersection en explorant les volumes de contra inte simultanément.

L'intersection entre plusieurs volumes de contrainte garantit rarement la résolution complète

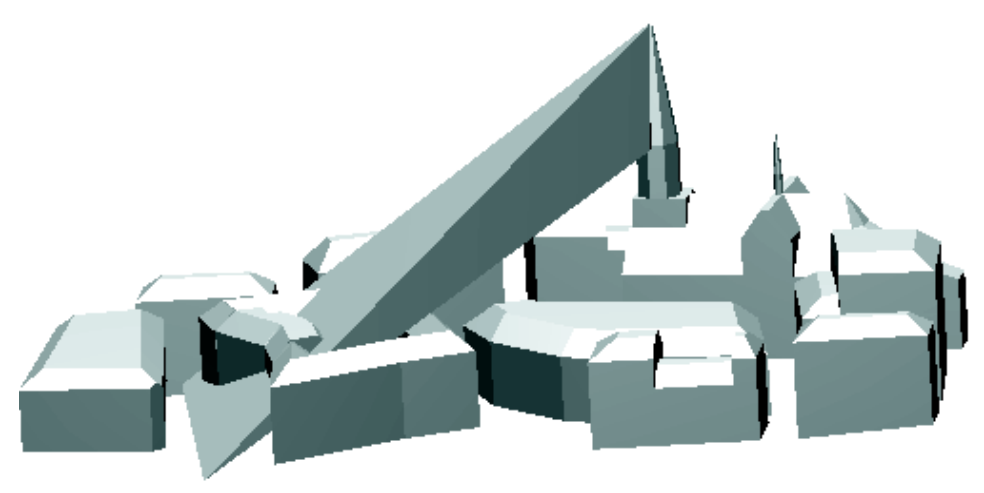

Figure 10: Intersection of visual constraint and site. [Intersection de la contrainte visuelle avec le site.]
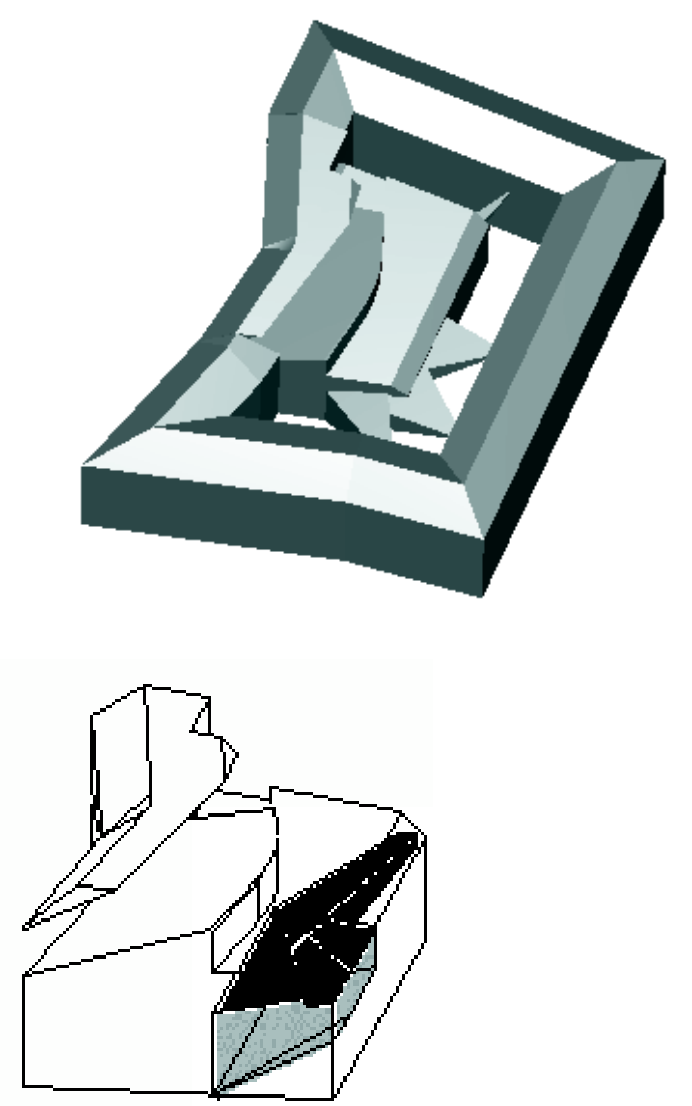

Figure 11: Translation of the privacy intent [Traduction de l'intention d'intimité.] 
He will therefore state a new intent:"from the window s of neighboring buildings don't see all of the hall (i.e. not picture window). W ith this as his goal, he selects the picture window's surface to be the target object selects the wind ow $s$ of the neighboring buildings as observation points 9 in our case four points). Figure 11 shows the constraint volumes thus generated.

In order to respond to this new constraint, the architect could decide to place the adminisrative office spaces to the rear of the land plot. These offices will be used for occluding the neighboring façades and thus to satisfy the privacy intent.

\section{conclusions}

In this paper we have presented an original method for taking into account, in a CAD system, intents rela ted to sunlight, visibility, and urban regulation. W e explained the principles of computing constraint volumes engendered by the sta tement of intents. W e have show $n$ that it is possible to unify the method of searching for solutions in these constra int volumes. Constraint volumes constitute new search spaces that restore, to some extent, a link between shape and phenomena in a CAD tool.

0 ur approach is of interest from tw 0 points of view Firstly, in the context of tea ching A rchitecture, making phenomena concrete in a virtual design space leads to a better understanding of them. An Architecture student can freely manipulate these phenomena and the shapes that are generated. Second, in a real-life situa tion our direct simulation approach allows one to visualize the behavior of several shapes representing some phenomena. The architect describes his project precisely only when he has found an acceptable compromise by playing with intents.

C urrently every phenomenon is processed by a different system. W e propose this unique tool with the hope of furthering students and practicing architects' interest in the method of design by intents. This research, only in its initial stages, must thoroughly examine how to deal with interactions between constraints. Some work in this direction has a Irea dy been done. In particular, we a re studying the possibilities of exploration by graphical means in some complex cases where an imporatant number of intents must be considered. W ithout aiming at solving all the constraints of a $n$ a rchitectural or urban design project, we wish to extend the formalism to other physical phenomena. In particular, we will have to study thermal or acoustical phenomena in order to judge the relevance of our approach for taking them into account in the early stages of the design process.

acknowledgments

The authors are grateful to $M$ arie-joelle Anto ine and Franck Raymond for their assistance with the English version of this paper.

\section{references}

Benedikt, M. L, 1979. "To Take Hold of Space: Isovist and Isovist Fields," Environment and Planning $B$, vol 6, pp 47-65.

Benedikt, M. L and Burnham, C. A, 1985. Perceiving Architectural Space: From 0 ptic Arrays to Isovists, Persistence and Change, $W$. H. W a rren, R. E. Shaw (eds), pp 103-114.

Danahy, J. and Hoinkes, R., 1995. "Polytrim: Collaborative Setting for Environmental Design,"in The G lobal Design Studio, M ilton Tam and Robert The (eds). N ational University of Singapore, 1995.

Do, E. Y-L and G ross, M. D., 1997. "Tools For Visual and Spatial A nalysis of CAD M odels," in Implementing Computer Tools as a M eans to Thinking about Architecture, Proceedings of CAAD Futures'97, M unich, pp 189-202.

Dubois-M aury J., 1996. "L'a ména gement urba in," 0 utils juridiques et forme urbaine, Eds. Dalloz Paris, collection pratique de l'Immobilier.

Dupagne, A., Leclercq, P. et Pirotte D., 1988. "Système basé sur de la connaissance appliquée à la réglementation urbaine," EuroplA'8 8 : Journées européennes sur les applications de l'intelligence artificielle en a rchitecture, bâtiment et génie civil, Paris, 28 29 novembre 1988.

Dupagne, A. and Teller, J., 1997 . "Représentation de l'espace ouvert dans un système d'information de projet urbain," Ingénierie des systèmes d'information, vol 5, pp 219-239.

Elmakhchouni, M., 1985. Contribution à l'étude d'un système graphique intelligent pour la planification urbaine: SYG RIPOS simulation

acadia'98

Asso ciation for C omputer-Aided Design in Architecture 
de l'ensemble des intentions engagées, c'està-dire qu'un seul masque ne peut satisfaire toutes les contraintes complètement. Toutefo is il peut être intéressant de travailler dans cet espace lorsque I'on cherche à optimiser des solutions. C ette recherche est rendue difficile par la géométrie complexe du volume d'intersection couplée au fa it que l'on doit prendre en compte la direction des rayons. Une première approximation de la solution consiste à offrir le volume d'intersection dans son entier (Figure $6 \mathrm{~b}$ ). C ependant d'autres masques sont acceptables (Figure $6 \mathrm{c}$ ).

$\mathrm{N}$ ous procédons actuellement à l'étude des propriétés associées aux volumes d'intersections entre contra intes. $N$ ous essayons de classifier les arrêtes et les faces de tels volumes en fonction des contraintes pour en extraire des méthodes de recherche de solutions. C ette classification doit nous permettre de connaître, pour chaque face du volume, son rôle dans la résolution des contraintes (taux de résolution, contrainte concernée) et ainsi aider à l'optimisation du placement d'un masque.

\section{exemple}

L'exemple que nous présentons prend en compte des intentions visuelles et urba ines. II s'a git de construire un complexe culturel en milieu urbain. Le programme inclut un auditorium, un hall de réception ainsi que divers loca ux administratifs. De plus les autorités locales demandent d'assurer une bonne visibilité d'un monument remarquable, situé aux abords du site, depuis la rue bordantla parcelle à construire. En outre le règ lement d'urbanisme en vigueur dans cette zone impose le respect d'un gabarit. Le schéma ci-dessous (Figure 7 ) présente en gris so mbre la parcelle à construire et en gris clair, le monument sur lequel porte la contrainte visuelle (en pointillé). La contrainte de gabaritdonne une première approximation du volume constructible (Figure 8). C oncrètementl'utilisa teur du système indique son intention visuelle en dessinant la zone de présence de l'observateur (point, segment, surface plane convexe) et en désignant la surface visée. II indique au système la parcelle à construire par un simple clic. II choisi da ns une liste l'ensemble des règles urbaines à appliquer. Dans notre exemple, les règles de volume maximal, de hauteur et de décrochement sont retenues. La règle d'emprise au sol n'est pas considérée.
La résolution du problème proposé met en évidence les difficultés inhérentes à la réalisation de contraintes multiples pouvant entrer en concurrence. L'intention visuelle « voir le monument » est une contrainte négative binaire en concurrence avec le volume de contrainte positif non binaire défini par les règles urbaines (Figure 10). Appliquant la règle de priorité, le système propose un évidement du volume gabarit (Figure 9).

La résolution de la première intention visuelle donne naissance à une ébauche de volume constructible sur lequel l'architecte travaille. II imagine installer l'audito rium dans la partie supérieure. Une circulation extérieure sur l'arrière permettra aux usagers d'avoir également une belle vue sur le monument. L'espace inférieur sera occupé par le hall de réception.

L'architecte pense réaliser une grande baie vitrée côté cour mais souhaite préserver l'intimité du hall. Il énonce alors une nouvelle intention: "Des fenêtres des bâtiments voisins, ne pas vo ir intég ra lement le hall (i.e. la surface vitrée)». Pour cela il désigne la surface de la grande baie comme l'objet regardé et selectionne les fenêtres à prendre en compte comme zones d'observation, en l'occurrence quatre points. La Figure 11 montre les volumes de contraintes engendrés. Pour répondre à cette nouvelle contrainte, l'architecte décide de placer les locaux a dministratifs à l'a rrière de la parcelle. Ils feront office de masques vis à vis des façades voisines.

\section{conclusions}

$N$ ous avons présenté dans cet article une méthode originale de prise en compte, dans un système de $\mathrm{CAO}$, des intentions de conception relatives à l'ensoleillement, la visibilité et la réglementation urbaine. Les principes de détermination des volumes de contrainte eng endrés par l'énoncé d'intentions ont été exposés. Nous avons montré qu'il est possible d'unifier les méthodes de recherche de solutions à l'intérieur de ces volumes. Ces nouvea ux espaces de recherche que constituent les volumes de contrainte rétablissent, dans une certaine mesure, un lien entre forme et phénomène en situation d'utilisation de l'outil informatique.

$\mathrm{N}$ otre approche possède deux intérêts 
visuelle des plans d'occupation des sols. Thèse de doctorat, Institut national des sciences appliquées de Lyon, $167 \mathrm{p}$.

Faucher, D., 1998. "Étude des règ les urbaines relatives à la morphologie du bâti en vue de leur modélisation informatique," Rapport de recherche IRIN $n^{\circ} 172$, Université de $N$ antes, $31 \mathrm{p}$.

Flemming, U., 1994. "G et with the Program: Common Falla cies in $C$ ritiques of $C$ omputer-Aided Architectural Design," Environment and Planning B: Planning and Design, vol21, pp 106 116.

G roleau, D., M arenne, C. and G adilhe, A., 1993. "C limatic simulation tools: an application for a building project in a urban space," Solar Energy in Architecture and Urban Planning, Proceedings of 3 rd European conference on architecture, Florence, pp 346-349.

G ro(, M., 1991. "The Analysis of Visibility, Environmental Interactions between Computer $G$ raphics, Physics, and Physiology," C omputer \& G raphics, vol 15, no 3:407-415.

G rau, K. and Johnsen, K.,1995. G eneral shading model for solar building design, ASHRAE Transactions, vol 101, Pt 2, 1995, $13 \mathrm{p}$.

Hillier, B., 1996. "C ities as movement economies," Urban Design International, Cambridge University Press, vol 1, no 1:41-60.

Koglin, H.-J. and Zewe, R., 1995 . "Valuation System for the Visibility of 0 verhead lines," Engineering Intelligent Systems, vol 3, no 4:195203.

Lahti, P., 1997. "G eographic Information Systems (G IS) as an interactive platform for economical management of urban planning," Ingénierie des systèmes d'information, vol 5 , no $2: 241-252$.

Lebahar, J. C., 1983. "Le dessin d'architecte : simulation graphique et réduction d'incertitude," Parenthèses, Collection Architecture / O utils, $134 \mathrm{p}$.

liggett, R. S., and Jepson, W. H., 1995. "An integ rated environment for urban simulation," Environmentand Planning B: Planning and Design, vol 22:291-302.

M iller, D. R., M orrice J., Horne P. and Aspinall R., 1994. "Characterization of Landscape Views," Macaulay Land Use Research Institute, EG IS 94, 10 p.

M orin, M ., 1995. "Lecture de la tour de Bretagne, développement d'un outil de lecture de la ville, simulation de l'accessibilité visuelle," Ecole d'Architecture de $\mathrm{N}$ antes.

M VRDV, 1996. "Aménagement d'une place sur une ancienne gare de triage à Bergen op Zoom," L'architecture d'aujourd'hui, no $306: 66-67$.

N ivet, M.-L. and Siret, D., 1998. "Simulation inverse de l'accessibilité visuelle en milieu urbain," Revue Internationale de CFAO, à paraitre.

$N$ ivet M -LDe Visu, 1997. "Approche déclarative pour la prise en compte de l'accessibilité visuelle dans le projet architectural ou urbain," Rapportde recherche IRIN, no165, Université de $\mathrm{N}$ antes.

Rabie, J., 1991. "Tow ards the simulation of urban morphology," Environment and Planning B: Planning and Design, Computers in the modelling and simulation of urban built form, vol 18, 1991, pp 57-70.

Siret, D., 1996. "Sunlighting Design: An Inverse Approach of Simulation for CAD Tools," Advances in Computer-Aided Design, Proceedings of CADEX'96, pp 32-40.

Siret, D., 1997. Propositions pour une approche déclarative des a mbiances dans le projet architectural. Application à l'ensoleillement. Thèse de doctorat, Université de $\mathrm{N}$ antes.

Sylvestrini, G. and Cacopardi S., 1993. "Uses of an Expert System for Pa ssive C ooling Building Design," in Proceedings, Third European Conference on Architecture (Solar Energy in Architecture and Urban Planning), Florence, pp 358-360.

Yezioro, A. and Shaviv, E., 1994. "Analysing $M$ utual Shading Between Buildings in an U rban Environment," in Proceeding s of PLEA'9 4. 
majeurs :

- Dans le cadre d'un enseignement en architecture, la matérialisation des phénomènes dans un espace virtuel de conception en permet une meilleure appréhension. L'étudiant en a rchitecture peut librement jouer a vec ces phénomènes et mieux comprendre les formes qu'ils induisent.

- En situation réelle, associée à l'approche de simulation directe, elle permet de visualiser le comportement de plusieurs configurations face à certains phénomènes. L'architecte ne s'engage dans une description précise $d u$ projet qu'a près un jeu sur les intentions lui ayant permis de trouver un compromis acceptable et ce dès les phases amont de conception.

Actuellement chaque phénomène est tra ité par un outil informatique particulier. A terme, nous souhaitons réunir au sein d'un même prototype logiciel les méthodes expérimentées, dans le but de valider l'intérêt de la conception par l'intention auprès des étudiants et praticiens.

Cette recherche, loin d'être aboutie, doit considérer à présent avec une grande rigueur les interactions entre contraintes. Des travaux en ce sens ont commencé. En particulier nous étudions les possibilités d'exploration graphique dans des cas complexes mettant en œuvre un nombre important d'intentions. Sans pour autant prétendre résoudre la to talité des contraintes du projet architectural ou urbain, nous espérons pouvoir étendre le formalisme à d'autres phénomènes. En particulier certains phénomènes thermiques, acoustiques ou aérauliques devront être étudiés avec rigueur afin de juger de la pertinence de notre approche pour leur prise en compte dans les phases amonts de la conception.

\section{remerciements}

$\mathrm{N}$ ous tenons à remercier $\mathrm{M}$ elle $\mathrm{M}$ arie-joelle Antoine et $M$. Franck Raymond pour leur aide précieuse quant à la rédaction de la version anglaise de cet article. 